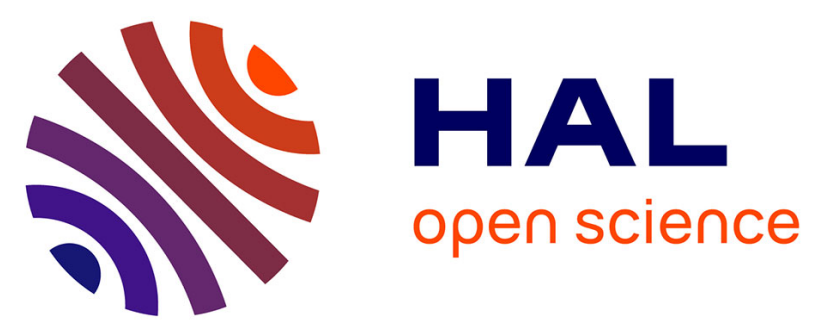

\title{
C-H Bond Arylation of Pyrazoles at the $\beta$-Position: General Conditions and Computational Elucidation for a High Regioselectivity
}

Xinzhe Shi, E Daiann Sosa Carrizo, Marie Cordier, Julien Roger, Nadine Pirio, Jean-Cyrille Hierso, Paul Fleurat-Lessard, Jean-François Soulé, Henri Doucet

\section{To cite this version:}

Xinzhe Shi, E Daiann Sosa Carrizo, Marie Cordier, Julien Roger, Nadine Pirio, et al.. C-H Bond Arylation of Pyrazoles at the $\beta$-Position: General Conditions and Computational Elucidation for a High Regioselectivity. Chemistry - A European Journal, 2021, 27 (17), pp.5546-5554. 10.1002/chem.202100031 . hal-03157416

\author{
HAL Id: hal-03157416 \\ https://hal.science/hal-03157416
}

Submitted on 15 Jun 2021

HAL is a multi-disciplinary open access archive for the deposit and dissemination of scientific research documents, whether they are published or not. The documents may come from teaching and research institutions in France or abroad, or from public or private research centers.
L'archive ouverte pluridisciplinaire HAL, est destinée au dépôt et à la diffusion de documents scientifiques de niveau recherche, publiés ou non, émanant des établissements d'enseignement et de recherche français ou étrangers, des laboratoires publics ou privés. 


\title{
$\mathrm{C}-\mathrm{H}$ Bond Arylation of Pyrazoles at the $\beta$-Position: General Conditions and Computational Elucidation for a High
}

\section{Regioselectivity}

\author{
Xinzhe Shi, ${ }^{[a]}$ E. Daiann Sosa Carrizo, ${ }^{[b]}$ Marie Cordier, ${ }^{[a]}$ Julien Roger, ${ }^{[b]}$ Nadine Pirio, ${ }^{[b]}$ Jean-Cyrille \\ Hierso, ${ }^{[b]}$ Paul Fleurat-Lessard, ${ }^{*[b]}$ Jean-François Soulé ${ }^{*[a]}$ and Henri Doucet ${ }^{\star[a]}$
}

[a] Ms X. Shi, Ms M. Cordier, Dr. J.-F. Soulé, Dr. H. Doucet

Univ Rennes, ISCR-UMR 6226

F-35000 Rennes, France

E-mail: jean-francois.soule@univ-rennes1.fr; henri.doucet@univ-rennes1.fr

[b] Dr. E. D. Sosa Carrizo, Dr. J. Roger, Pr. Dr. N. Pirio, Pr. Dr. J.-C. Hierso, Pr. Dr. P. Fleurat-Lessard

Université de Bourgogne, Institut de Chimie Moléculaire de l'Université de Bourgogne, UMR CNRS 6302

Université de Bourgogne Franche-Comté (UBFC)

9 avenue Alain Savary, 21078 Dijon (France)

Email: paul.fleurat-lessard@u-bourgogne.fr

Supporting information for this article is given via a link at the end of the document.

\begin{abstract}
Direct arylation of most five-membered ring heterocycles are generally easily accessible and strongly favored at the $\alpha$-position using classical palladium-catalysis. Conversely, regioselective functionalization of such heterocycles at the concurrent $\beta$-position remains currently very challenging. Herein, we report general conditions for regioselective direct arylation at the $\beta$-position of pyrazoles, while $\mathrm{C}-\mathrm{H} \alpha$-position is free. By using aryl bromides as the aryl source and a judicious choice of solvent, the arylation reaction of variously $N$-substituted pyrazoles simply proceeds via $\beta-\mathrm{C}-\mathrm{H}$ bond functionalization. The $\beta$-regioselectivity is promoted by a ligand-free palladium catalyst and a simple base without oxidant or further additive, and tolerates a variety of substituents on the bromoarene. DFT calculations revealed that a protic solvent such as 2ethoxyethan-1-ol significantly enhances the acidity of the proton at $\beta$ position of the pyrazoles and thus favors this direct $\beta-\mathrm{C}-\mathrm{H}$ bond arylation. This selective pyrazoles $\beta-\mathrm{C}-\mathrm{H}$ bond arylation was successfully applied for the straightforward building of $\pi$-extended poly(hetero)aromatic structures via further Pd-catalyzed combined $\alpha$ $\mathrm{C}-\mathrm{H}$ intermolecular and intramolecular $\mathrm{C}-\mathrm{H}$ bond arylation in an overall highly atom-economical process.
\end{abstract}

\section{Introduction}

Several very important drugs contain a 4-(hetero)arylpyrazole unit without substituent at the C5-position of the pyrazole ring (Figure 1). ${ }^{[1]}$ For example, Crizotinib is an anti-cancer drug approved in 2011 for the treatment of some non-small cell lung carcinoma. Encorafenib is a drug approved in 2018 for the treatment of certain melanomas. Baricitinib is a drug approved in 2017 for the treatment of rheumatoid arthritis. Erdafitinib is investigated in the treatment of bile duct cancer, gastric cancer, non-small cell lung cancer, and esophageal cancer. Moreover, it was granted in March 2018, breakthrough therapy designation by the U.S. Food and Drug Administration for treatment of urothelial cancer and approved in $\mathbf{2 0 1 9}$ for the treatment of bladder cancer. Finally, Avapritinib was approved in 2020 to treat patients with unresectable or metastatic gastrointestinal stromal tumors. In recent years, several methods for the preparation of substituted pyrazoles have been reported such as addition-cyclization, [2 + 2 +1 ] annulation or ring-opening/cyclization. ${ }^{[2]}$ However, there is still a need for simple and effective methods for the preparation of 4-arylpyrazoles.

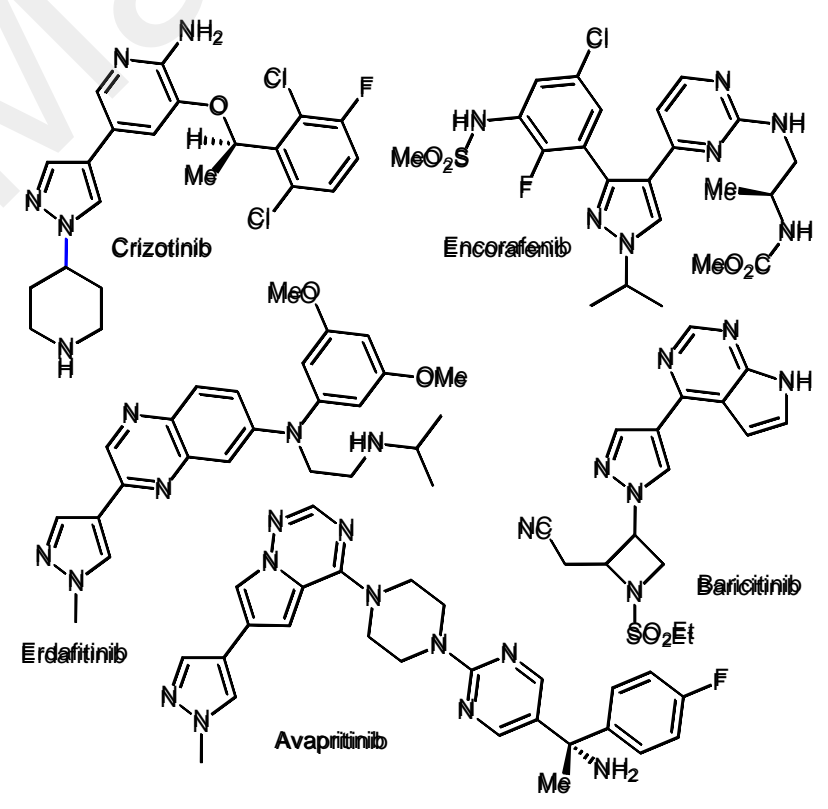

Figure 1. Examples of drugs containing a 4-(hetero)arylpyrazole unit.

Metal-catalyzed direct functionalization of (hetero)arene $\mathrm{C}-\mathrm{H}$ bonds is a very powerful atom-economical synthetic method for the convergent synthesis of valuable polyaromatics. ${ }^{[3]}$ Yet, the diversity of $\mathrm{C}-\mathrm{H}$ bonds present in heterocycles may result in selectivity issues potentially very challenging to handle with. The inherent electronic bias of the heterocycle itself often orientates the regioselectivity of direct $\mathrm{C}-\mathrm{H}$ bond arylation reaction. For example, in the $\mathrm{C}-\mathrm{H}$ bond functionalization of furans, thiophenes, selenophenes, pyrroles, imidazoles and triazoles, palladiumcatalyzed direct $\alpha$-arylation is generally favored (Figure 2, left). ${ }^{[4,5]}$ Interestingly, in a few cases it has been found that $\beta$-position is 
accessible for arylation by using specific conditions such as alternative coupling partners $\left(\mathrm{ArSiR}_{3}, \mathrm{ArBR}_{2}, \mathrm{ArSO}_{2} \mathrm{R}\right)$ and/or specific catalysts, bases and additives (Figure 2, right). However, such regiodivergent reactions of five-membered heterocyclic rings, in the absence of introduced directing groups, remains limited to thiophenes, ${ }^{[6 a]}$ thiazoles, ${ }^{[6]}$ and selenophenes. ${ }^{[6 c]}$

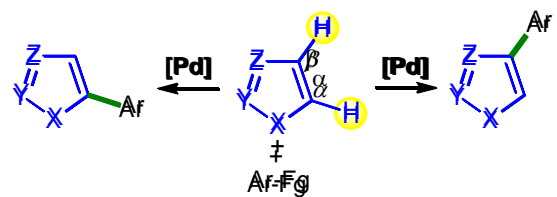

$\mathrm{Fg} \equiv \mathrm{Cl}, \mathrm{Br}_{1}, \mathrm{I}, \mathrm{SiR}_{3} ; \mathrm{B}_{2} ; \mathrm{SO}_{2} \mathrm{R}$

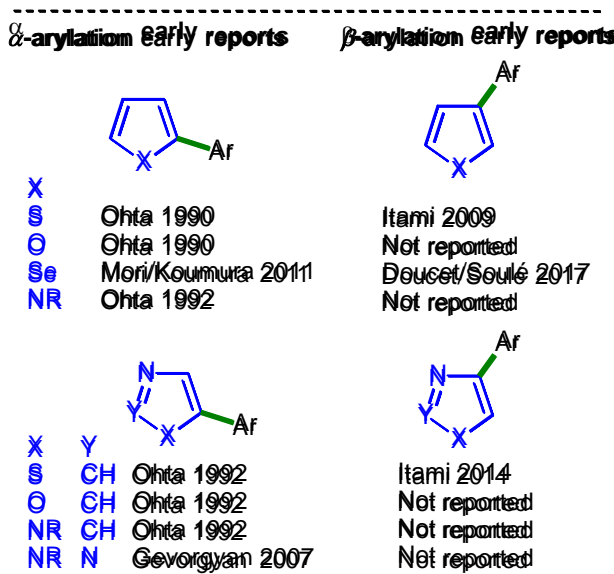

Figure 2. Palladium-catalyzed regiodivergent arylation reactions of fivemembered heteroarenes.

Several procedures for the Pd-catalyzed regioselective $\alpha$ arylation of pyrazoles have been reported (Scheme 1a). ${ }^{[7,8]}$ The use of pyrazole unit in palladium- or rhodium-catalyzed alkenylations via $\mathrm{C}-\mathrm{H}$ bond activation has also been described. ${ }^{[9]}$ Conversely, only a few examples of $\beta$-arylation of pyrazoles have been reported, which involve $\alpha$-substituted pyrazoles. ${ }^{[10]}$ Alternatively, coupling reactions using $\mathrm{Au} / \mathrm{Ag}$ catalyzed dehydrogenative process with polyfluoroarenes as the aryl source have been described by Zhu and co-workers (Scheme 1b), which strongly limit the scope of the reaction. ${ }^{[1]}$ Clearly, general synthetic conditions for the regioselective direct arylation at $\beta$ position of unsubstituted pyrazoles with non-fluorinated aryl sources, are highly desirable (Scheme 1 , bottom). ${ }^{[2,13]}$

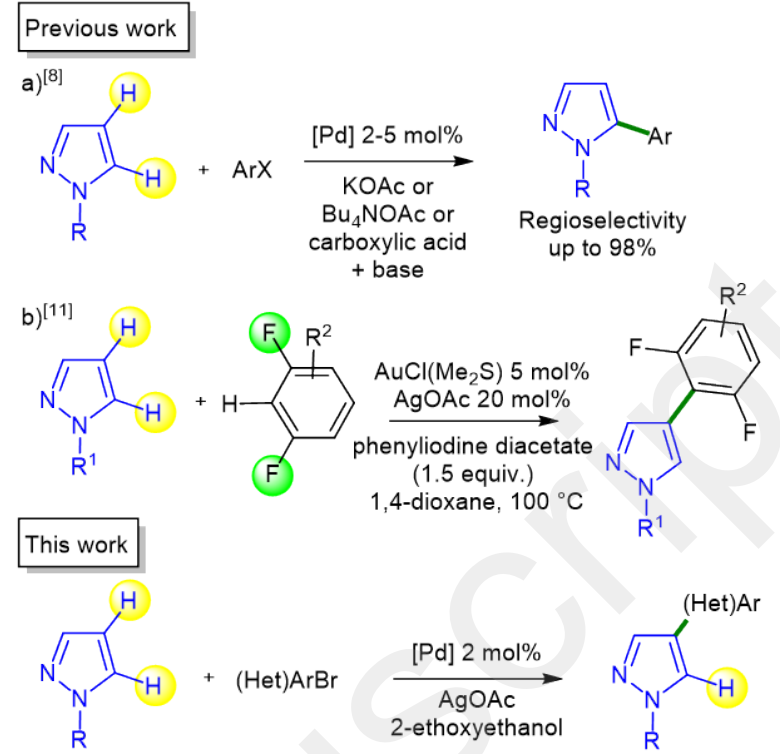

Scheme 1. Direct $\alpha$ - or $\beta$-arylation reactions of pyrazoles.

Accordingly, we report herein on the influence of several reaction conditions on the regioselectivity in the Pd-catalyzed arylation of pyrazoles via $\mathrm{C}-\mathrm{H}$ bond functionalization. The decisive role of the solvent and base at the origin of the regiodivergent selectivities observed was evaluated through DFT computations.

\section{Results and Discussion}

Under standard $\mathrm{C}-\mathrm{H}$ functionalization conditions, ${ }^{[8 \mathrm{~b}]}$ we examined the regioselectivity of the arylation of 3 equiv of 1 isopropylpyrazole with 4-bromobenzonitrile, in DMA at $150{ }^{\circ} \mathrm{C}$ during $16 \mathrm{~h}$ (Table 1). Unsurprisingly, by using $2 \mathrm{~mol} \%$ of $\mathrm{Pd}(\mathrm{OAc})_{2}$ or $\mathrm{PdCl}_{2}(\mathrm{MeCN})_{2}$ as catalysts, and 2 equiv of $\mathrm{KOAc}$ as the base, intractable mixtures of $\alpha$ - and $\beta$-arylated pyrazoles $\mathbf{1 a}$, $\mathbf{1 b}$, plus diarylated pyrazole 1c were obtained. The $\alpha$-arylated pyrazole $1 \mathbf{a}$ was mostly obtained in any case (Table 1 , examples in entries 1 and 2). Using $\mathrm{K}_{2} \mathrm{CO}_{3}$ as base, a poor conversion of the aryl bromide was obtained with $\mathrm{PdCl}_{2}(\mathrm{MeCN})_{2}$, and again, the $\alpha$-arylated product 1a was the major regioisomer (Table 1, entry 3). Pleasingly, the use of $\mathrm{AgOAc}$ as the base with $\mathrm{PdCl}_{2}(\mathrm{MeCN})_{2}$ gave $\beta$-arylated pyrazole $\mathbf{1 b}$ with a ratio $\mathbf{1 a}: \mathbf{1 b}$ of $20: 80$, and only a low amount of was 1c formed (Table 1, entry 4); however, a partial conversion of the bromoarene below $50 \%$ was noticed. The use of mixtures of bases, such as 2 equiv of $\mathrm{KOAc}$ or $\mathrm{K}_{2} \mathrm{CO}_{3}$ associated with 0.1 equiv of $\mathrm{AgOAc}$, did not improved the regioselectivity in $\beta-\mathrm{C}-\mathrm{H}$ arylated regioisomer $\mathbf{1 b}$ (Table 1, entries 5 and 6).

Therefore, the influence of solvents was examined, especially for improving the substrate conversion. In 2-ethoxyethan-1-ol, using AgOAc as a base, a quantitative conversion of 4bromobenzonitrile was achieved with a regioselectivity favoring the desired product $\mathbf{1 b}$. $\mathrm{Pd}(\mathrm{OAc})_{2}$ and $\mathrm{PdCl}_{2}(\mathrm{MeCN})_{2}$ catalysts, allowed the formation of $\mathbf{1 b}$, which was isolated in $57 \%$ and $61 \%$ yield, respectively (Table 1, entries 7 and 8). In 2-ethoxyethan-1ol, KOAc could be used as base without regioselectivity modification compared with AgOAc, but the undesired formation of (1,1'-biphenyl)-4,4'-dicarbonitrile was also observed from 
homocoupling of 4-bromobenzonitrile (Table 1, entry 9). Notably, using a $\mathrm{Pd}(0)$ source (such as $\left[\mathrm{Pd}(\mathrm{dba})_{2}\right]$ ) instead of a $\mathrm{Pd}(\mathrm{II})$ provided the products $\mathbf{1 a - 1 c}$ with a regioselectivity conserved, suggesting that the mechanism is likely to proceed via a
$\operatorname{Pd}(0) / P d(I I)$ catalytic cycle (Table 1 , entry 10$)$. The selectivity of the reaction using other palladium catalysts, bases and solvents is described in the Table S1 in the supporting information.

Table 1. Influence of the reaction conditions on the regioselectivity of the $\mathrm{C}-\mathrm{H}$ bond arylation of 1-isopropylpyrazole. ${ }^{[a]}$

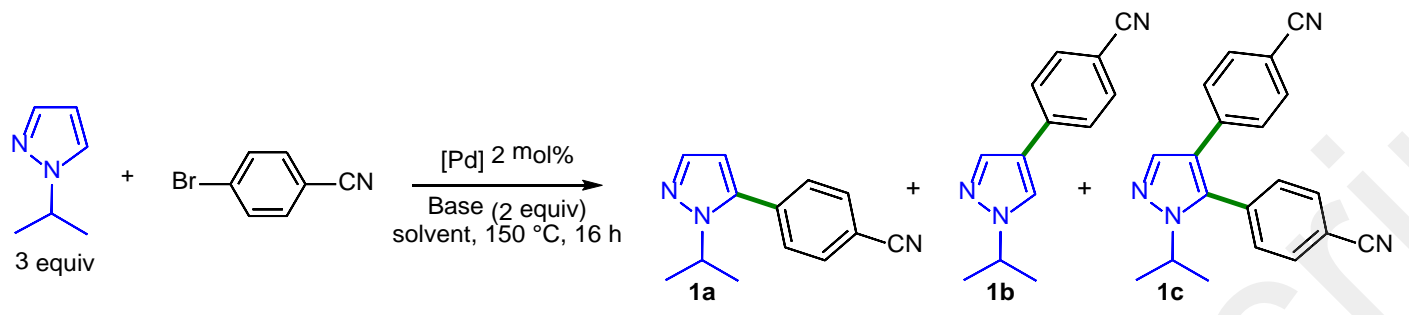

\begin{tabular}{|c|c|c|c|c|c|c|}
\hline Entry & [Pd] (2 mol\%) & Base (2 equiv) & Solvent & Conv. (\%) & $\begin{array}{c}\text { Ratio } \\
\text { 1a:1b:1c }\end{array}$ & $\begin{array}{c}\text { Yield in } \mathbf{1 b} \\
(\%)\end{array}$ \\
\hline 1 & $\mathrm{Pd}(\mathrm{OAc})_{2}$ & KOAC & DMA & 73 & $41: 31: 28$ & 19 \\
\hline 2 & $\mathrm{PdCl}_{2}(\mathrm{MeCN})_{2}$ & KOAC & DMA & 68 & $35: 29: 36$ & 15 \\
\hline 3 & $\mathrm{PdCl}_{2}(\mathrm{MeCN})_{2}$ & $\mathrm{~K}_{2} \mathrm{CO}_{3}$ & DMA & 13 & $78: 22: 0$ & - \\
\hline 4 & $\mathrm{PdCl}_{2}(\mathrm{MeCN})_{2}$ & AgOAc & DMA & 54 & 19:75:6 & 38 \\
\hline 5 & $\mathrm{PdCl}_{2}(\mathrm{MeCN})_{2}$ & $\mathrm{~K}_{2} \mathrm{CO}_{3}+\mathrm{AgOAc}$ (0.1 equiv) & DMA & 43 & $79: 21: 0$ & - \\
\hline 6 & $\mathrm{PdCl}_{2}(\mathrm{MeCN})_{2}$ & $\mathrm{KOAc}+\mathrm{AgOAc}$ (0.1 equiv) & DMA & 31 & $40: 60: 0$ & 17 \\
\hline 7 & $\mathrm{Pd}(\mathrm{OAc})_{2}$ & $\mathrm{AgOAc}$ & 2-ethoxyethan-1-ol & 99 & $20: 66: 14$ & 57 \\
\hline 8 & $\mathrm{PdCl}_{2}(\mathrm{MeCN})_{2}$ & AgOAc & 2-ethoxyethan-1-ol & 99 & 19:68:13 & 61 \\
\hline 9 & $\mathrm{PdCl}_{2}(\mathrm{MeCN})_{2}$ & KOAC & 2-ethoxyethan-1-ol & 93 & $20: 75: 5$ & $26^{[\mathrm{b}]}$ \\
\hline 10 & $\mathrm{Pd}(\mathrm{dba})_{2}$ & AgOAc & 2-ethoxyethan-1-ol & 88 & $19: 72: 9$ & - \\
\hline
\end{tabular}

[a] [Pd] 2 mol\%, 1-isopropylpyrazole (3 equiv), $150{ }^{\circ} \mathrm{C}, 16 \mathrm{~h}$, conversion based on consumption of 4-bromobenzonitrile, conversions and ratios of $1 \mathbf{a}: 1 \mathbf{b}: 1 \mathrm{c}$ determined by GC and NMR of the crude mixtures, isolated yields. [b] (1,1'-Biphenyl)-4,4'-dicarbonitrile was formed in high yield (60\%).

Based on the high conversion and good regioselectivity conditions we determined, the substrate scope and the functional tolerance of $\beta-\mathrm{C}-\mathrm{H}$ pyrazole arylation was investigated. First, the influence of the substituent hold on the nitrogen atom of pyrazole was determined (Scheme 2). Using 4-bromobenzonitrile as the aryl source, similar results were obtained with isopropyl and cyclohexyl substituents. A decrease of selectivity was observed for the arylation of 1-methylpyrazole compared to 1isopropylpyrazole with 2-bromobenzonitrile (ratio 4a:4b 37:63 vs 5a:5b 9:91). The substituents on the aryl bromide also significantly influence the regioselectivity of the arylation. For example, the use of 2-bromonitrobenzene or 2(trifluoromethyl)bromobenzene gave the regioisomers $\mathbf{6 b}$ and $\mathbf{8 b}$ in notably high $97 \%$ and $92 \%$ regioselectivity, respectively. Conversely, the use of 2-bromofluorobenzene gave the regioisomer $\mathbf{9 b}$ in $78 \%$ selectivity. The reaction tolerates several other functions on the aryl bromide such as ester and formyl groups, affording $\mathbf{3 b}$ and $\mathbf{7 b}$ in $54 \%$ and $61 \%$ yield, respectively. The reaction of 1-isopropylpyrazole with 1-bromonaphthalene also afforded the desired $\beta$-arylated pyrazole $\mathbf{1 2 b}$ in a high regioselectivity of $89 \%$.
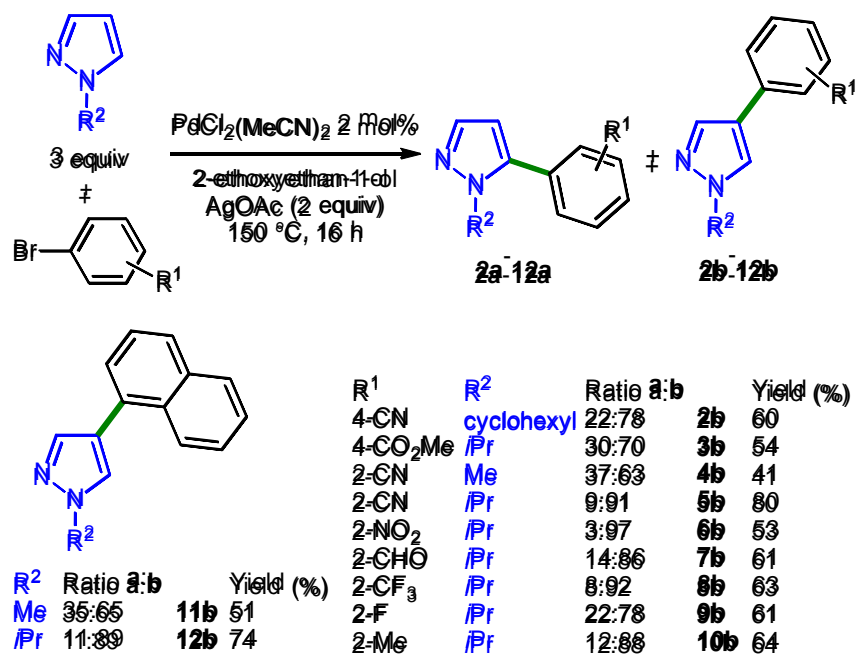

Scheme 2. Scope of $\beta$-arylation of 1-alkylpyrazole derivatives.

1-Phenylethyl substituent hold on the nitrogen atom of heteroaromatic substrates is a protecting group that can be removed by several convenient methods. ${ }^{[14]}$ Therefore, the 
reactivity and regioselectivity of 1-(1-phenylethyl)pyrazole as the pyrazole source was investigated under our general conditions (Scheme 3). Pleasingly, in most cases, high regioselectivity favoring $\beta$-arylations was achieved. Direct arylation from bromoarenes bearing cyano, nitro, propionyl, benzoyl, ester, formyl or trifluoromethyl para-substituents, gave the expected 4arylpyrazoles $\mathbf{1 3 b - 1 9 b}$ in $86-93 \%$ regioselectivity, isolated in 72 $81 \%$ yields. Substituents at meta-position were also well tolerated, with 3-bromobenzonitrile, 3-bromonitrobenzene and 3bromoacetophenone giving the products 20b-22b with $82-85 \%$ regioselectivity, isolated in $70-73 \%$ yields. In general, the use of a more hindered aryl bromide afforded 4-arylpyrazole with higher regioselectivity. 2-Cyano- and 2-nitro-substituted aryl bromides gave the products $\mathbf{2 5 b}$ and $\mathbf{2 6 b}$ in $95 \%$ and $98 \%$ regioselectivity, respectively. We examined the opportunity to extend the $\beta$ functionalization to heteroaryl bromides using our catalytic conditions. Both 3-bromoquinoline and 4-bromoisoquinoline gave the desired biheteroaryls $\mathbf{2 9 b}$ and $\mathbf{3 1 b}$ with high regioselectivity (80\% and 94\%, respectively). From 2-acetyl-5-bromothiophene, compound 32b was also obtained in a high regioselectivity (93\%) and in good yield (60\%).
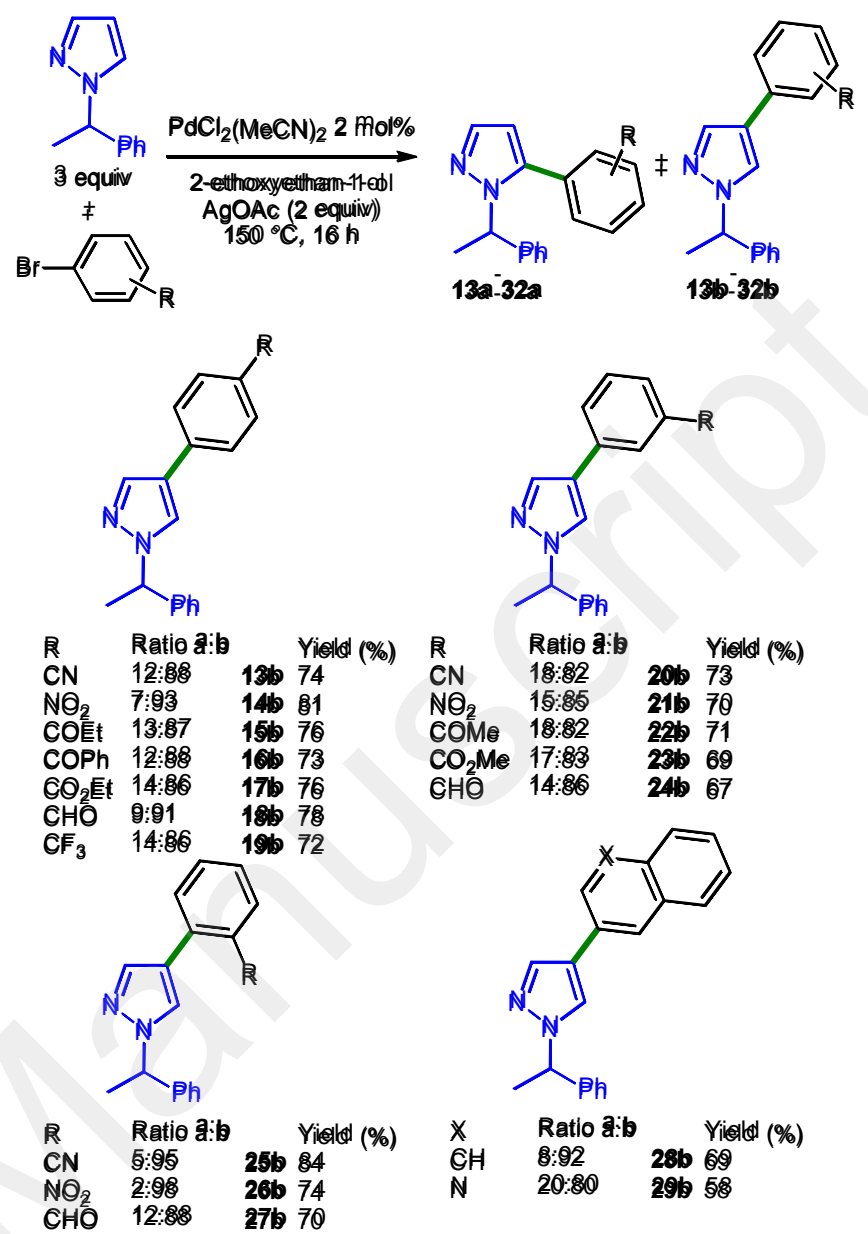

(1)
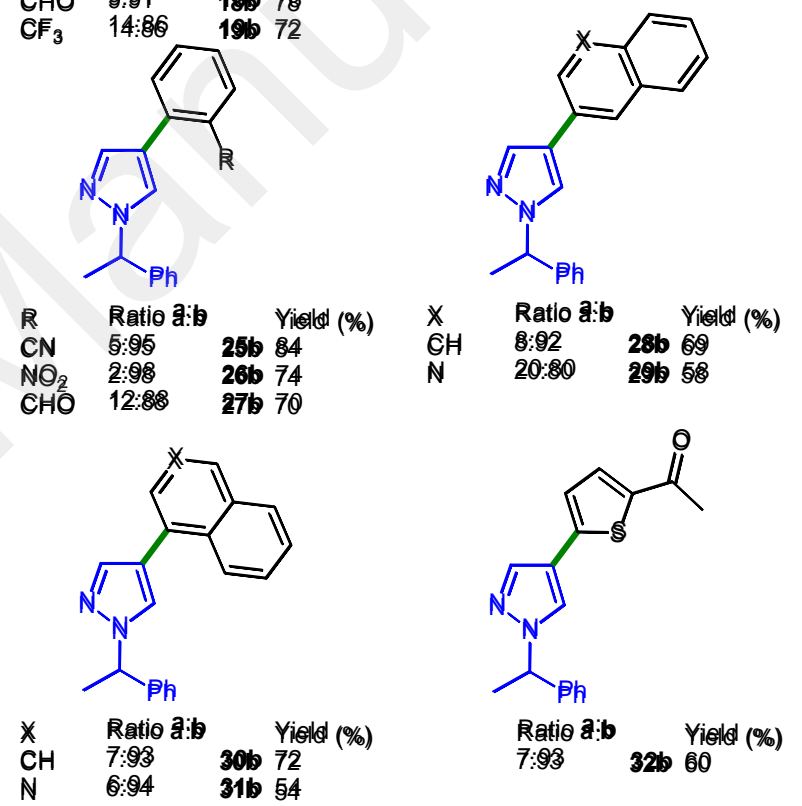

Scheme 3. Scope of the $\beta$-arylation of 1-(1-phenylethyl)pyrazole.

Since benzyl is also a common protecting group of heteroarenes $^{[15]}$ the regioselectivity of the arylation of 1benzylpyrazole was further examined (Scheme 4). In most cases, slightly lower regioselectivity, still in favor of $\beta$-arylation, were observed under our conditions. However, in general reasonable to good yields of arylpyrazole can be obtained. Thus, reaction using 4- and 2-bromobenzonitriles afforded the products $\mathbf{3 3 \mathbf { b }}$ and 36b in $69 \%$ and $76 \%$ yield, respectively ( $80-85 \%$ selectivity). Highly selective $\beta$-arylation was observed with the congested aryl bromides 2-bromonitrobenzene and 2(trifluoromethyl)bromobenzene (95\% and 94\%). Using the heteroaryl bromides 4-bromoisoquinoline and 2-acetyl-5bromothiophene the regioselectivity for coupling 1-(1phenylethyl)pyrazole (products $\mathbf{3 1 b}$ and $\mathbf{3 2 b}$ ) and 1benzylpyrazole (products $\mathbf{4 1 b}$ and $\mathbf{4 2 b}$ ) were similarly above $90 \%$. 

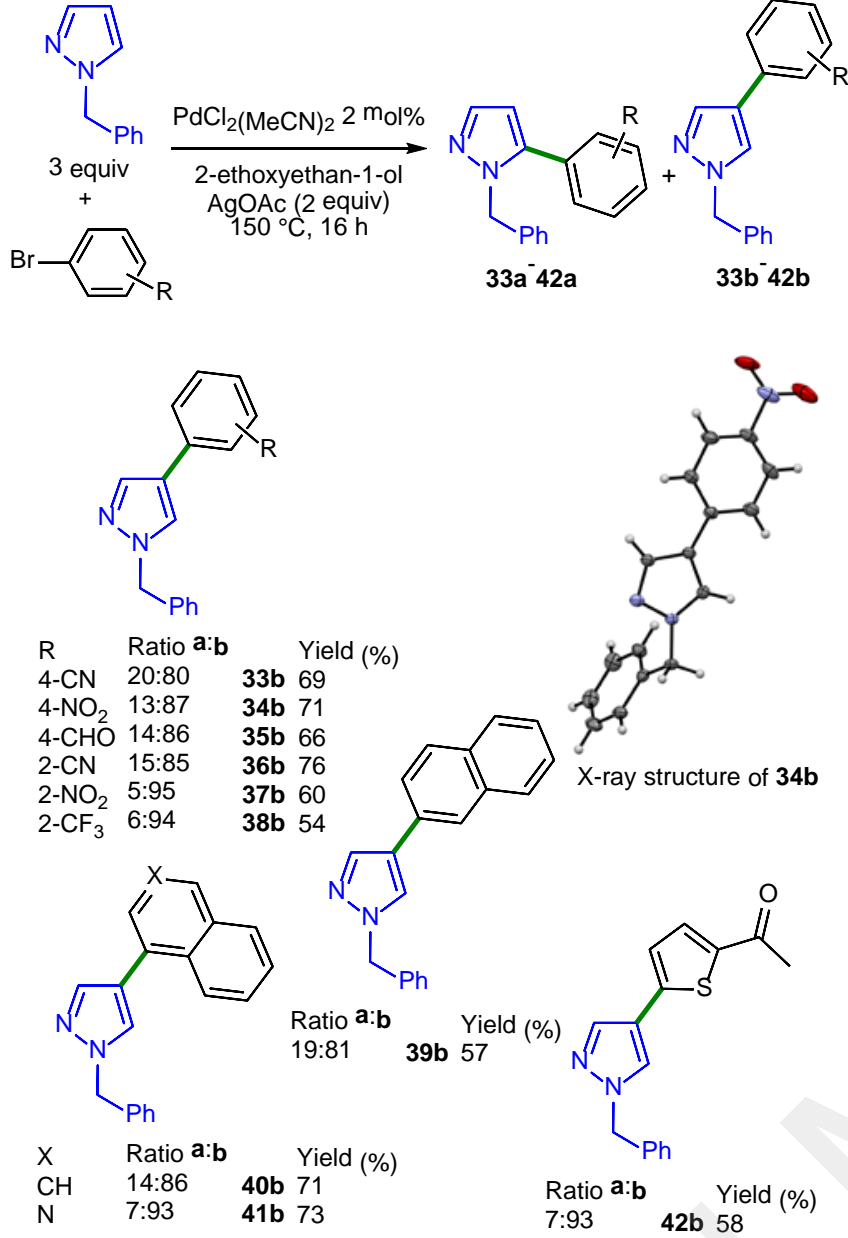

Scheme 4. Scope of the $\beta$-arylation of 1-benzylpyrazole.

The regioselectivity of the arylation of a 3-substituted pyrazole was also studied (Scheme 5). From 3-methyl-1-phenylpyrazole and 2-bromonitrobenzene, the C4-arylated pyrazole 43b was obtained in $76 \%$ regioselectivity and in $41 \%$ yield, revealing that the presence of a methyl substituent at the pyrazole C3-position has a negative influence on the regioselectivity.

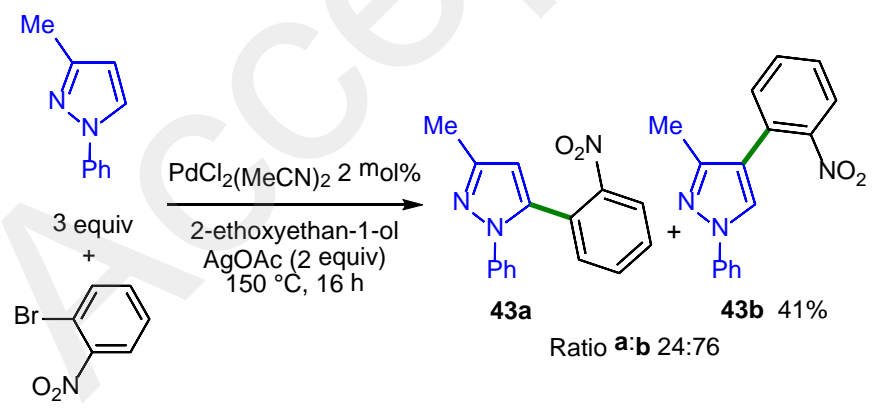

Scheme 5. $\beta$-Arylation of a 3-substituted pyrazole

It should be mentioned that the reactivity of the $N$-heterocycle substituted pyrazole 1-(tetrahydro-2H-pyran-2-yl)pyrazole was also examined, as the tetrahydropyranyl unit is a convenient protecting group. However, very low yields in coupling products, which could not be isolated, were detected by GC/MS analysis of the crude mixtures using 4-bromobenzonitrile or 1bromonaphthalene as the reaction partners in the presence of 2 mol\% $\mathrm{PdCl}_{2}(\mathrm{MeCN})_{2}$, AgOAc (2 equiv.) in 2-ethoxyethan-1-ol at $150{ }^{\circ} \mathrm{C}$ during $6 \mathrm{~h}$. The use of NMP, DEC or DMA as the solvent also led to very poor conversions of the aryl bromides.

$\alpha-\mathrm{C}-\mathrm{H}$ bond position of pyrazoles is known to be reactive for direct arylation reactions with aryl halides using palladium catalysis in the presence of acetate bases. ${ }^{[8]}$ We thus examined the opportunity to further $\alpha-\mathrm{C}-\mathrm{H}$ functionalize the 4-arylpyrazoles previously formed, this possibly leading to valuable unsymmetrically polysubstituted heteroaromatics (Scheme 6). ${ }^{[16,17]}$ Compound $\mathbf{3 5 b}$ was reacted with a set of aryl bromides in the presence of $2 \mathrm{~mol} \%$ of $\mathrm{Pd}(\mathrm{OAc})_{2}$ catalyst, and KOAc as the base in DMA. The $\alpha, \beta$-diarylated products $\mathbf{4 4 - 4 6}$ were obtained in $52-87 \%$ yields using the electron-poor 4-bromobenzonitrile, 4fluorobromobenzene and the electron-rich 4-tertbutylbromobenzene. The lower yield obtained with 4-tertbutylbromobenzene was due to a partial conversion of this unactivated aryl bromide. From $\mathbf{1 b}$ and 4-bromobenzonitrile, the $\alpha, \beta$-diarylpyrazole bearing two identical aryl groups was obtained in $83 \%$ yield. Conversely, the $\alpha$-arylation of 4 -naphthylpyrazole 40b gave the products 47 and 48 in moderate yields $(\mathbf{4 8}, 47 \%)$.
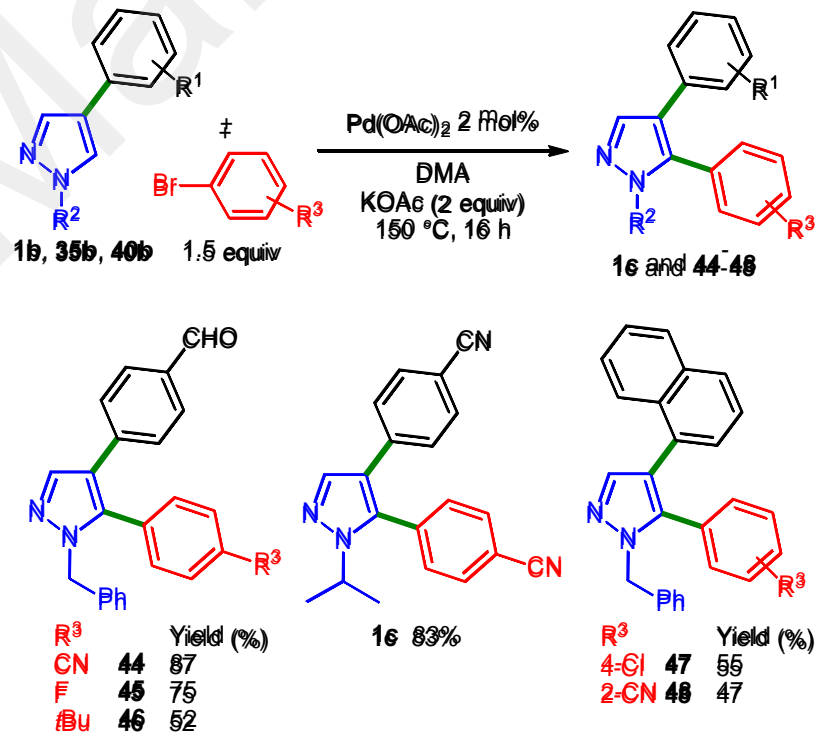

Scheme 6. Scope of the $\alpha$-arylation of 4-aryl-1-(1-benzyl)pyrazoles or 4-(1isopropylpyrazol-4-yl)benzonitrile.

A variety of methods for the deprotection of benzyl-substituted heteroarenes have been reported, ${ }^{[15]}$ and accordingly the deprotection of 1-benzyl-4-(naphthalen-1-yl)pyrazole 40b was very efficiently achieved in short reaction time (Scheme 7). The reaction of $40 \mathrm{~b}$ with $t \mathrm{BuOK}$ with $\mathrm{O}_{2}$ bubbling afforded the desired 4-(naphthalen-1-yl)pyrazole 49 in 91\% yield. 


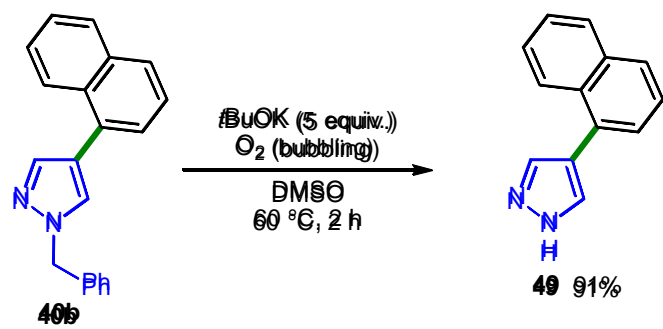

Scheme 7. Deprotection of 1-benzyl-4-(naphthalen-1-yl)pyrazole 40b

In order to gain more insight into the origin of the divergent regioselectivity in this $\mathrm{Pd}$-catalyzed direct $\beta-\mathrm{C}-\mathrm{H}$ bond arylation, we used Density Functional Theory (see Computational Details) to compute the Gibbs free energy profiles for direct arylation involving $\mathrm{Pd}(0)$ and 4-bromobenzonitrile in DMA (Figure 3) and 2ethoxyethan-1-ol (Figure 4).

The mechanism depicted in Figure 3 begins with the oxidative addition (OA) of 4-bromobenzonitrile (Ar1) to Pd(pyrazole) 2 . The OA starts from the initial $\mathrm{Pd}(0)-\pi-c o m p l e x$ add- $\pi\left(5.8 \mathrm{kcal} \mathrm{mol}^{-1}\right)$, which is then transformed into the $\mathrm{Pd}(\mathrm{II})$ complex int 1 in a highly exergonic process $\left(\Delta \mathrm{G}=-24.8 \mathrm{kcal} \mathrm{mol}^{-1}\right)$. This transformation takes place through a typical three-membered transition state ts$\mathrm{OA}$ with the simultaneous formation of the $\mathrm{Pd}-\mathrm{C}$ and the $\mathrm{Pd}-\mathrm{X}$ bonds. The concerted metalation-deprotonation (CMD) step then takes place similarly to previously reported. ${ }^{[18-23]}$ It is noteworthy that the pyrazole involved in the CMD step is already coordinated to the palladium atom. Both ts1-C $\beta$ and ts1-C $\alpha$ transition states proceed with a five-membered structure, associated with the simultaneous $\mathrm{Pd}-\mathrm{C}$ and $\mathrm{O}-\mathrm{H}$ bond formation and $\mathrm{C} \ldots \mathrm{H}$ bond breaking. The activation barriers differs only by $0.5 \mathrm{kcal} \mathrm{mol}^{-1}$ in favor of ts1-C $\alpha\left(\Delta \mathrm{G}^{\ddagger}=21.3 \mathrm{kcal} \mathrm{mol}^{-1}\right.$ for $\beta$-position and $\Delta \mathrm{G}^{\ddagger}=$ $20.8 \mathrm{kcal} \mathrm{mol}^{-1}$ for $\alpha$-position). The arylation at $\alpha$-position is thus slightly favored. Under kinetic control this $0.5 \mathrm{kcal} \mathrm{mol}^{-1}$ difference leads to a $\alpha: \beta$ product ratio of $65: 35$, which reasonably agrees with the experimental observations (Table 1, entries 1-3 and 5-6).

This preference comes from the fact that the proton in $\alpha$-position is more acidic. This is also characterized by ts $1-\mathrm{C} \alpha$ being an early transition state (TS), structurally closer to reagents than products, contrary to ts1-C $\beta$. Thus, $\mathrm{C}-\mathrm{H}$ and $\mathrm{Pd}-\mathrm{O}$ bonds to be broken are shorter in ts1-C $\alpha$ than in the late TS ts1-C $\beta$ : $\mathrm{C}-\mathrm{H}=1.29 \AA$ and
$\mathrm{Pd}-\mathrm{O}=2.18 \AA$ in ts1- $\mathrm{C} \alpha$ vs $\mathrm{C}-\mathrm{H}=1.39 \AA$ and $\mathrm{Pd}-\mathrm{O}=2.22 \AA$ in ts1-C $\beta$.

The reductive elimination takes place to give the final products 1a and $\mathbf{1 b}$. To this end, the HOAc/L ligand exchange generates int4 in an exergonic process. From int4 the formation of final product takes place through the reductive elimination involving the ts2. The ts $\mathbf{2}-\mathbf{C} \boldsymbol{\beta}$ and ts $\mathbf{2}-\mathbf{C} \boldsymbol{\alpha}$ transition states are associated with the simultaneous formation of the $\mathrm{C}-\mathrm{C}$ bond and the Pd-C $\mathrm{C}_{\mathrm{Ar} 1}$ and $\mathrm{Pd}-\mathrm{C}_{\mathrm{Ar} 2}$ bond breaking. Notably, these results indicate that in DMA, in the absence of silver participation, the $\alpha$-arylation is kinetically favored, in full agreement with the experimental results.

Interestingly, when 2-ethoxyethan-1-ol is used as solvent (Figure 4), the computed CMD activation barriers are reversed compared to the DMA case and differ by $1.4 \mathrm{kcal} \mathrm{mol}^{-1}: \Delta \mathrm{G}^{\ddagger}=$ $20.8 \mathrm{kcal} \mathrm{mol}^{-1}$ for $\beta$-arylation, and $\Delta \mathrm{G}^{\ddagger}=22.2 \mathrm{kcal} \mathrm{mol}^{-1}$ for $\alpha$ arylation. The arylation at $\beta$-position is more clearly favored, in agreement with experimental results. This inversion in selectivity from $\alpha$-favored to $\beta$-favored induced by the solvent, comes from the protic nature of the 2-ethoxyethan-1-ol. The hydrogen bonding $\mathrm{N}$... H-O (1.77 $\AA$ for ts1-C $\alpha$ and $1.75 \AA$ for ts $1-\mathrm{C} \beta)$, as shown in Figure 4 (and $\mathrm{SI}$ for full profile), involving the lone pair of pyrazole nitrogen with the hydroxyl group of 2-ethoxyethan-1-ol strongly modifies the heterocycle electronic features. This is wellillustrated by the very different change of partial charges occurring at the protons in $\alpha$ and $\beta$-position. The solvation change from DMA to 2-ethoxyethan-1-ol makes the partial charge of the proton in $\beta$ position increasing by $28 \%$ (from 0.043 to 0.055 coulomb), while at the same time the partial charge of the proton in $\alpha$-position increases by only $9 \%$ (from $0.083 \mathrm{C}$ to $0.090 \mathrm{C}$ ). Additionally, the entropic effects destabilize more the early TS ts1-C $\alpha$ (Figure 4 , $\mathrm{C}-\mathrm{H} 1.30 \AA$ ) than the late TS ts1-C $\boldsymbol{\beta}$ (Figure 4, C-H $1.39 \AA$ ).

The combination of this $\beta$-acidity increase and ts1-C $\alpha$ destabilization is decisive in the regioselectivity inversion in 2ethoxyethan-1-ol. Consistently, under kinetic control the computed Gibbs free energy difference of $1.4 \mathrm{kcal} \mathrm{mol}^{-1}$ leads to an estimated theoretical $\alpha: \beta$ product ratio of $15: 85$, in fair agreement with the general trends of all the experimental crosscouplings conducted in 2-ethoxyethan-1-ol. The resulting catalytic cycle is shown in Figure 5. 


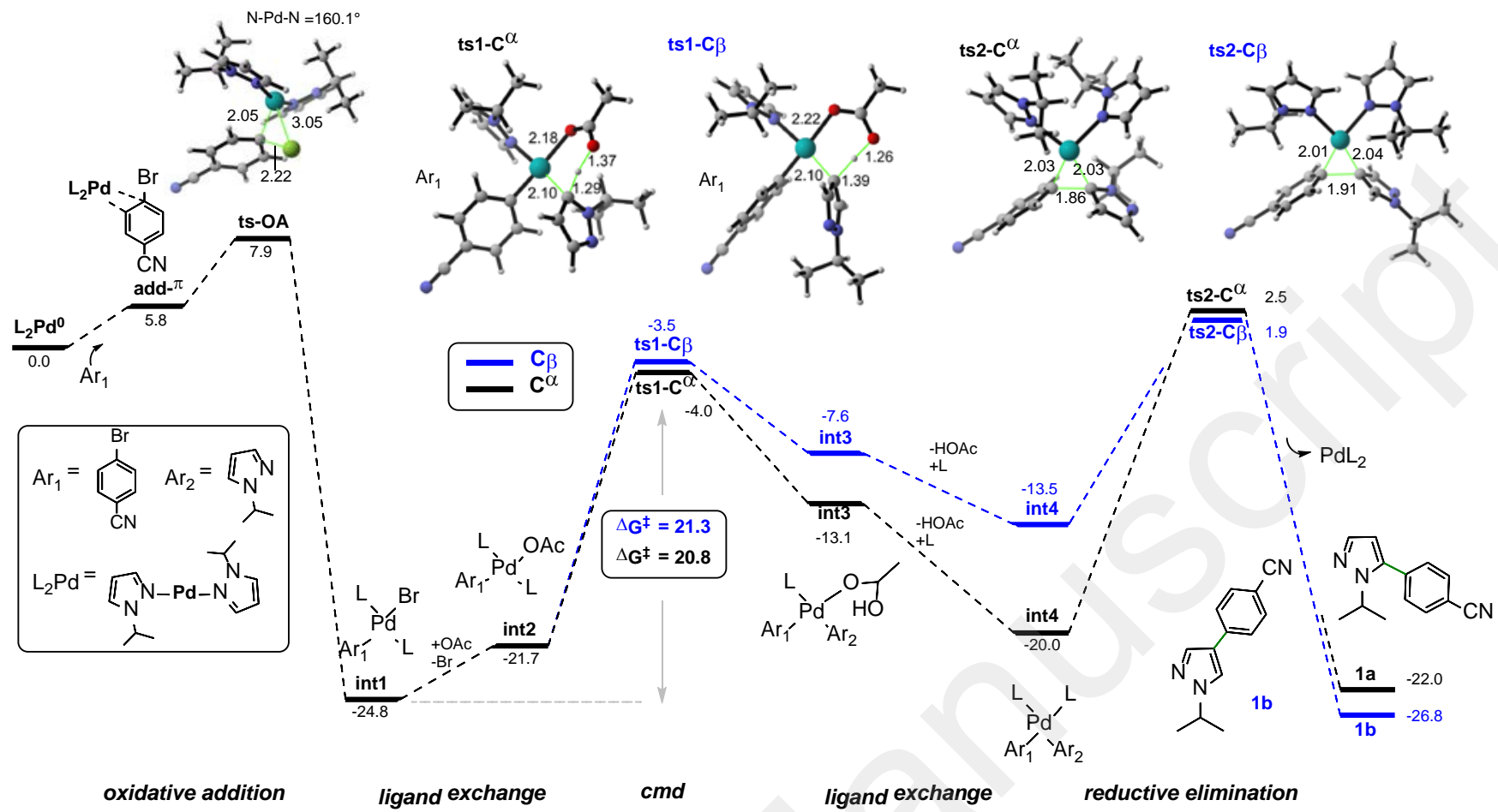

Figure 3. Gibbs free energy profile $\left(\mathrm{kcal} \mathrm{mol}^{-1}\right)$ computed for the Pd-catalyzed arylation at $150{ }^{\circ} \mathrm{C}$ in DMA. Key distances are given in $\AA$. Atom color code: $\mathrm{C}=$ grey, $\mathrm{H}=$ white, $\mathrm{N}=$ blue, $\mathrm{O}=$ red, $\mathrm{Pd}=$ cyan and $\mathrm{Br}=$ green.

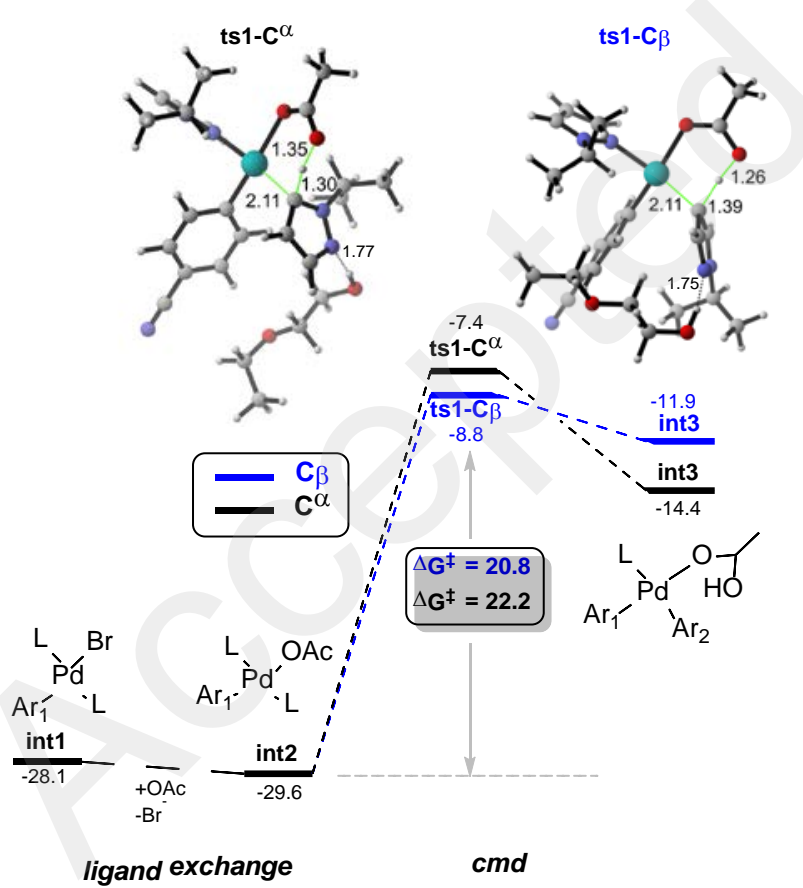

Figure 4. Gibbs free energy profile for the $\mathrm{C}-\mathrm{H}$ activation computed in 2ethoxyethan-1-ol at $\mathrm{T}=150^{\circ} \mathrm{C}$. Selected pertinent distances are given in $\AA$.

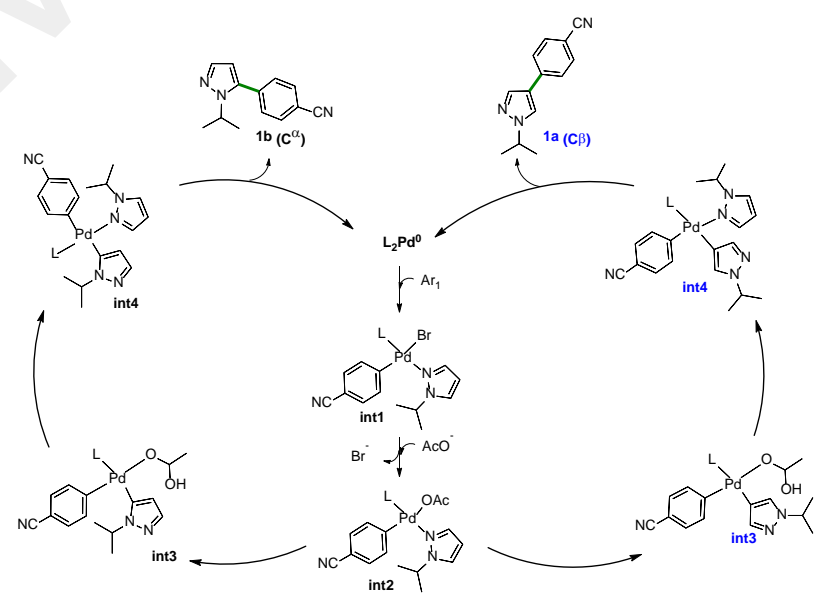

Figure 5. Proposed catalytic cycle without silver salt.

We also further considered the role of silver salts in the arylation of 1-isopropylpyrazole. In our hands, a silver promoted process was not amenable to a highly efficient catalytic process with $\beta$-C$\mathrm{H}$ arylation regioselectivity. Experimentally, a stoichiometric amount of AgOAc was necessary and 0.1 equiv was detrimental to the conversion (see Table 1), while the absence of palladium was ineffective. As detailed in the Supplementary Information, silver can be involved in many ways. ${ }^{[24]}$ We found that it could activate the $\beta$ position by binding to the lone pair of the pyrazole similarly to the action of the 2-ethoxyethan-1-ol solvent (Figure 6 in 2-ethoxyethan-1-ol, and Figure S3-Th in DMA in ESI). A lower activation barrier was calculated for $\mathrm{C}-\mathrm{H}$ activation occurring at the $\beta$-C $\left(\Delta \mathrm{G}^{\ddagger}=29.3 \mathrm{kcal} \mathrm{mol}{ }^{-1}\right)$ in comparison to $\alpha-\mathrm{C}\left(\Delta \mathrm{G}^{\ddagger}=30.0\right.$ $\left.\mathrm{kcal} \mathrm{mol}^{-1}\right)$; this both in DMA and 2-ethoxyethan-1-ol. These 
results suggest that in DMA the regiodivergence is partly due to the complexation of silver to pyrazole. Conversely, in 2ethoxyethan-1-ol, the $\beta$-arylation process is favored with or without the participation of silver.

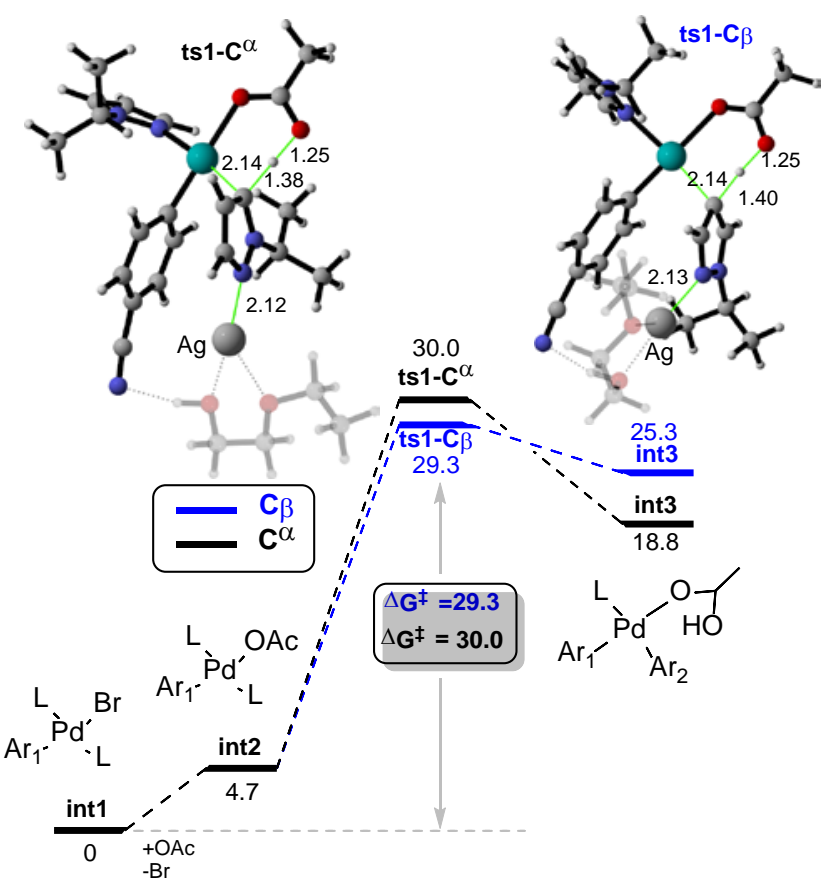

Figure 6. Gibbs free energy profile $\left(\mathrm{kcal} \mathrm{mol}^{-1}\right)$ for CMD process assisted by silver in 2-ethoxyethan-1-ol at $\mathrm{T}=150{ }^{\circ} \mathrm{C}$. Selected pertinent distances are given in $\AA$.

Palladium-catalyzed intermolecular arylation associated with intramolecular $\mathrm{C}-\mathrm{H}$ bond arylation is a straightforward method in the building of $\pi$-extended (hetero)polyaromatic structures, overwhelming more classical divergent multistep procedures. ${ }^{[17]}$ Thanks to the present alternative regioselectivity provided by our conditions, and usually of difficult access, we applied a Pdcatalyzed combined methodology to the synthesis of dibenzo[e,g]indazoles (Scheme 8). From N-methyl-4(naphthalen-1-yl)pyrazole $\mathbf{1 1 b}$ and 1,2-dibromobenzene in the presence of $2 \mathrm{~mol} \%$ of $\mathrm{Pd}(\mathrm{OAc})_{2}$ catalyst, the targeted benzo[g]naphtho[1,2-e]indazole $\mathbf{5 0}$ was obtained in $61 \%$ yield. The use of 1-bromo-2-iodobenzene reagents allows to selectively introduce a substituent at the C3-position of the benzo[g]naphtho[1,2-e]indazole, as the oxidative addition to palladium is faster for the $\mathrm{C}-\mathrm{I}$ bond than for the $\mathrm{C}-\mathrm{Br}$. Thus, using 1-bromo-3-methyl-6-iodobenzene, methyl-aryl compound $\mathbf{5 1}$ was obtained in very good $76 \%$ yield. Similarly, the chloro-substituted benzo[g]naphtho[1,2-e]indazole $\mathbf{5 2}$ was obtained in $53 \%$ yield from 1-bromo-3-chloro-6-iodobenzene. The $\mathrm{C}-\mathrm{Cl}$ bond remained untouched potentially allowing for further functionalization.

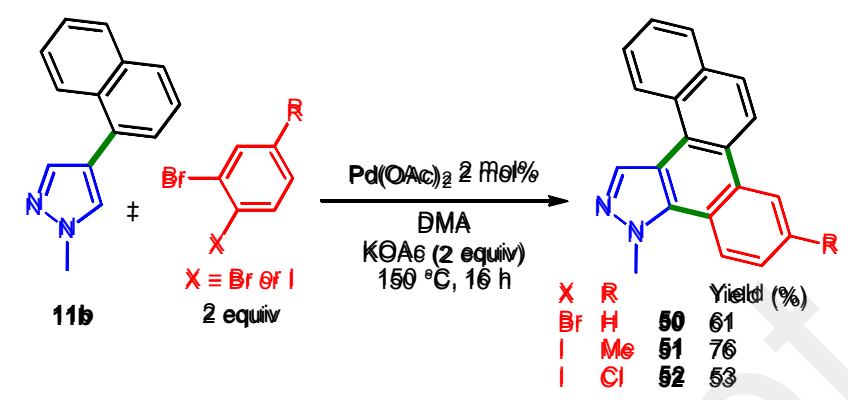

Scheme 8. Two steps, three $\mathrm{C}-\mathrm{H}$ bond arylation, straightforward synthesis of benzo[g]naphtho[1,2-e]indazoles.

\section{Conclusion}

Overall, we disclosed simple general conditions for the palladiumcatalyzed regioselective direct arylation at the $\beta$-position of pyrazoles, while until now the more acidic $\alpha$-position was the only one selectively reachable. This inedited regioselectivity is highly dependent on the nature of the solvent and the base. With ligandfree $\mathrm{Pd}(\mathrm{OAc})_{2}$ catalyst and AgOAc as base in 2-ethoxyethan-1-ol, the $\beta$-arylated pyrazoles were obtained in $70-98 \%$ regioselectivity with pyrazoles bearing isopropyl, cyclohexyl, benzyl, or 1phenylethyl substituents on the nitrogen atom. This procedure tolerates a variety of useful substituents on the aryl bromide. Due to the wide availability of diversely substituted pyrazoles and aryl bromides at an affordable cost, such simple reaction conditions (easily available catalyst, base and solvent) should be very attractive for synthetic chemists, giving a robust access to $\beta$ arylated pyrazoles. From the 4-arylpyrazole compounds formed, a second palladium-catalyzed $\mathrm{C}-\mathrm{H}$ bond functionalization at carbon $\mathrm{C} 5$ of the pyrazole ring gives an alternative synthetic pathway to unsymmetrically substituted 4,5-diarylpyrazoles. DFT computations showed that the 2-ethoxyethan-1-ol solvate exacerbates the acidity of the proton in $\beta$-position which eventually favors arylation in $\beta$-position. However, in DMA the $\beta$ arylation is only favored in the presence of AgOAc. Computations suggested in such cases, that the regioselectivity determining CMD step could be -at least partially- assisted by silver complexes. Ultimately, this new $\beta-\mathrm{C}-\mathrm{H}$ arylation method was applied for the easy synthesis of $\pi$-extended benzo[g]naphtho[1,2-e]indazoles by using 4-arylpyrazoles C-C coupling in a Pd-catalyzed intermolecular associated to intramolecular double $\mathrm{C}-\mathrm{H}$ bond arylation.

\section{Acknowledgements}

We thank the CNRS, the Université de Rennes I, the Université de Bourgogne (calculations performed using HPC resources from DSI-CCUB) and the ANR for financial support (ANR-PRC 2016 program ALCATRAS 16-CE07-0001-01). In Dijon, this work was also supported by the European Union through the PO FEDERFSE Bourgogne 2014/2020, and the Regional Council of Bourgogne Franche-Comté through the PIA-excellence ISITEBFC program CoMICS: Chemistry of Molecular Interactions Catalysis and Sensors.

Keywords: catalysis $\bullet \beta-\mathrm{C}-\mathrm{H}$ arylation $\bullet$ heterocycle $\bullet$ palladium - solvent effect 
[1] a) A. Shaw, U. Yasothan, P. Kirkpatrick, Nat. Rev. Drug Discov. 2011, 10, 897-898; b) K. Garber Nat. Biotechnol. 2013, 31, 3-4; c) P. Sidaway Nat. Rev. Clin. Oncol. 2018, 15, 344-345.

[2] For recent preparation methods of pyrazoles: a) D. Y. Li, X. F. Mao, H. J. Chen, G. R. Chen, P. N. Liu, Org. Lett. 2014, 16, 3476-3479; b) M. C. Pérez-Aguilar, C. Valdés, Angew. Chem., Int. Ed. 2015, 54, 13729-13733; c) R. S. Thombal, Y. R. Lee, Org. Lett. 2018, 20, 4681-4685; d) J. Liu, E. Xu, J. Jiang, Z. Huang, L. Zheng, Z.-Q. Liu, Chem. Commun. 2020, 56 2202-2005.

[3] For reviews on C-H bond functionalization: a) L. Ackermann, Chem. Rev. 2011, 111, 1315-1345; b) R. Rossi, F. Bellina, M. Lessi, C. Manzini, Adv. Synth. Catal. 2014, 356, 17-117; c) L. Djakovitch, F.-X. Felpin ChemCatChem 2014, 6, 2175-2187; d) L. Theveau, C. Schneider, C. Fruit, C. Hoarau, ChemCatChem 2016, 8, 3183-3194; e) S. Agasti, A. Dey, D. Maiti, Chem. Commun. 2017, 53, 6544-6556; f) T. Gensch, M. J. James, T. Dalton, F. Glorius, Angew. Chem. Int. Ed. 2018, 57, 22962306; g) J. Kalepu, P. Gandeepan, L. Ackermann, L. T. Pilarski, Chem. Sci. 2018, 9, 4203-4216; h) K. Hirano, M. Miura, Chem. Sci. 2018, 9, 22 32; i) P. Gandeepan, T. Mueller, D. Zell, G. Cera, S. Warratz, L. Ackermann, Chem. Rev. 2019, 119, 2192-2452; j) S. Rej, Y. Ano, N. Chatani, Chem. Rev. 2020, 120, 1788-1887.

[4] S. Mao, H. Li, X. Shi, J.-F. Soulé, H. Doucet, ChemCatChem 2019, 11 , 269-286.

[5] a) Y. Akita, A. Inoue, K. Yamamoto, A. Ohta, T. Kurihara, M. Shimizu, Heterocycles 1985, 23, 2327-2333; b) A. Ohta, Y. Akita, T. Ohkuwa, M Chiba, R. Fukunaga, A. Miyafuji, T. Nakata, N. Tani, Y. Aoyagi Heterocycles 1990, 31, 1951-1958; c) Y. Aoyagi, A. Inoue, I. Koizumi, R. Hashimoto, K. Tokunaga, K. Gohma, J. Komatsu, K. Sekine, A. Miyafuji, J. Kunoh, R. Honma, Y. Akita, A. Ohta, Heterocycles 1992, 33, 257-272 d) S. Tamba, R. Fujii, A. Mori, K. Hara, N. Koumura, Chem. Lett. 2011 40, 922-924; e) S. Chuprakov, N. Chernyak, A. S. Dudnik, V. Gevorgyan, Org. Lett. 2007, 9, 2333-2336.

[6] a) S. Yanagisawa, K. Ueda, H. Sekizawa, K. Itami, J. Am. Chem. Soc. 2009, 131, 14622-14623; b) S. Tani, T. N. Uehara, J. Yamaguchi, K. Itami, Chem. Sci. 2014, 5, 123-135; c) A. Skhiri, R. Ben Salem, J.-F. Soulé, H. Doucet, Chem. Eur. J. 2017, 23, 2788-2791.

[7] For a study on the regioselectivity of the arylation of pyrazoles: $R$. Goikhman, T. L. Jacques, D. Sames, J. Am. Chem. Soc. 2009, 131 3042-3048.

[8] For selected examples of Pd-catalyzed direct $\alpha$-arylations of pyrazoles: a) C. Mateos, J. Mendiola, M. Carpintero, J. M. Minguez, Org. Lett. 2010 12, 4924-4927; b) A. Beladhria, K. Beydoun, H. Ben Ammar, R. Ben Salem, H. Doucet, Synthesis 2011, 2553-2560; c) F. Bellina, M. Lessi, C. Manzini, Eur. J. Org. Chem. 2013, 5621-5630; d) E. T. T. Kumpulainen, A. Pohjakallio, Adv. Synth. Catal. 2014, 356, 1555-1561; e) H. Jung, S Bae, H.-L. Jang, J. M. Joo, Bull. Korean Chem. Soc. 2014, 35, 30093014; f) S. Fuse, T. Morita, K. Johmoto, H. Uekusa, H. Tanaka, Chem. Eur. J. 2015, 21, 14370-14375; g) W. F. Vernier, L. Gomez, Tetrahedron Lett. 2017, 58, 4587-4590.

[9] For the use of pyrazole unit in $\mathrm{C}-\mathrm{H}$ bond activation and related articles: a) H. T. Kim, H. Ha, G. Kang, O. S. Kim, H. Ryu, A. K. Biswas, S. M. Lim M.-H. Baik, J. M. Joo, Angew. Chem., Int. Ed. 2017, 56, 16262-16266; b) H. Kim, R. S. Thombal, H. D. Khanal, Y. R. Lee, Chem. Commun. 2019 55, 13402-13405; c) H. Cai, R. S. Thombal, X. Li, Y. R. Lee, Adv. Synth Catal. 2019, 361, 4022-4032.

[10] For examples of Pd-catalysed direct $\beta$-arylations of 3,5-disubstituted pyrazoles: a) S. Kumar, H. Ila, H. Junjappa, J. Org. Chem. 2009, 74 7046; b) Y. Fall, H. Doucet, M. Santelli Synthesis 2010, 127-135; c) F. Derridj, J. Roger, S. Djebbar, H. Doucet, Adv. Synth. Catal. 2012, 354, 747-750.

[11] For Au/Ag catalyzed dehydrogenative $\beta$-arylation of pyrazoles with polyfluoroarenes: W. Li, D. Yuan, G. Wang, Y. Zhao, J. Xie, S. Li, C. Zhu, J. Am. Chem. Soc. 2019, 141, 3187-3197.

[12] For recent examples of synthesis of 4-arylpyrazoles using Suzuki reaction: a) Y. Liang, M. Wispelaere, M. Carocci, Q. Liu, J. Wang, P. L. Yang, N. S. Gray, ACS Med. Chem. Lett. 2017, 8, 344-349; b) S. Mah, J. H. Park, H.-Y. Jung, K. Ahn, S. Choi, H. S. Tae, K. H. Jung, J. K. Rho, J. C. Lee, S.-S. Hong, S. Hong, J. Med. Chem. 2017, 60, 9205-9221; c) V. Trivedi-Parmar, M. J. Robertson, J. A. Cisneros, S. G. Krimmer, W. L.
Jorgensen, ChemMedChem 2018, 13, 1092-1097; d) Y. Shan, R. Si, J. Wang, Q. Zhang, H. Zhou, J. Song, J. Zhang, Q. Chen, Eur. J. Med. Chem. 2019, 440-447.

[13] For the synthesis of 4-arylpyrazoles using Negishi reaction: C. Wiethan, W. C. Rosa, H. G. Bonacorso, M. Stradiotto, Org. Biomol. Chem. 2016 , 14, 2352-2359.

[14] For selected examples of deprotection of 1-phenylethyl-substituted heteroarenes: a) A. J. Smith, A. Young, S. Rohrbach, E. F. O'Connor, M Allison, H.-S. Wang, D. L. Poole, T. Tuttle, J. A. Murphy, Angew. Chem., Int. Ed. 2017, 56, 13747-13751; b) S. Haldar, S. Saha, S. Mandal, C. K Jana, Green Chem. 2018, 20, 3463-3467.

[15] For selected examples of deprotection of benzyl-substituted heteroarenes: a) A. A. Haddach, A. Kelleman, M. V. Deaton-Rewolinski, Tetrahedron Lett. 2002, 43, 399-402; b) R. S. Foster, H. Adams, H Jakobi, J. P. A. Harrity, J. Org. Chem. 2013, 78, 4049-4064; c) A. W. Brown, M. Fisher, G. M. Tozer, C. Kanthou, J. P. A. Harrity, J. Med. Chem. 2016, 59, 9473-9488; d) O. Obulesu, K. H. Babu, J. B. Nanubolu, S. Suresh, J. Org. Chem. 2017, 82, 2926-2934.

[16] For recent development and applications see: C. D. Mboyi, C. Testa, S Reeb, S. Genc, H. Cattey, P. Fleurat-Lessard, J. Roger, J.-C. Hierso, ACS Catal. 2017, 7, 8493-8501.

[17] W. Hagui, H. Doucet, J.-F. Soulé, Chem 2019, 5, 2006-2078.

[18] D. L. Davies, S. A. Macgregor, C. L. McMullin, Chem. Rev. 2017, 117, 8649-8709.

[19] M. Lafrance, S. I. Gorelsky, K. Fagnou, J. Am. Chem. Soc. 2007, 129, 14570-14571.

[20] S. I. Gorelsky, D. Lapointe, K. Fagnou, J. Am. Chem. Soc. 2008, 130 10848-10849.

[21] D. García-Cuadrado, A. A. C. Braga, F. Maseras, A. M. Echavarren, J. Am. Chem. Soc. 2006, 128, 1066-1067.

[22] D. García-Cuadrado, P. de Mendoza, A. A. C. Braga, F. Maseras, A. M. Echavarren, J. Am. Chem. Soc. 2007, 129, 6880-6886.

[23] M. Lafrance, C. N. Rowley, T. K. Woo, K. Fagnou, J. Am. Chem. Soc 2006, 128, 8754-8756.

[24] a) M. D. Lotz, N. M. Camasso, A. J. Canty, M. S. Sanford, Organometallics 2017, 36, 165-171; b) K. L. Bay, Y. F. Yang, K. N. Houk, J. Organomet. Chem. 2018, 864, 19-25; c) B. Bhaskararao, S. Singh, M. Anand, P. Verma, P. Prakash, C. Athira, S. Malakar, H. F. Schaefer, R. B. Sunoj, Chem. Sci. 2020, 11, 208-216. 


\section{Entry for the Table of Contents}

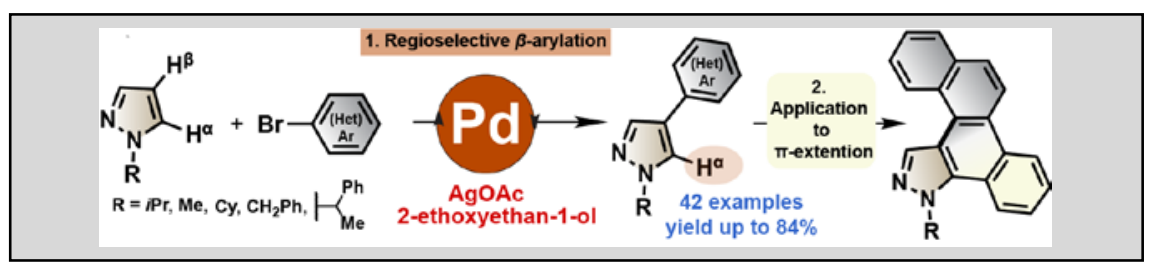

By using a very simple ligand-free palladium-catalyst and without directing group installation, the less-acidic $\beta$-C-H of pyrazoles is regioselectively arylated (up to 98\%) conserving untouched $\alpha-\mathrm{C}-\mathrm{H}$ bonds. 